\title{
Adapting adaptation: the English eco-town initiative as governance process
}

\author{
Daniel Tomozeiu ${ }^{1}$ and $\underline{\text { Simon Joss }}^{1}$
}

\begin{abstract}
Climate change adaptation and mitigation have become key policy drivers in the UK under its Climate Change Act of 2008. At the same time, urbanization has been high on the agenda, given the pressing need for substantial additional housing, particularly in southeast England. These twin policy objectives were brought together in the UK government's 'eco-town' initiative for England launched in 2007, which has since resulted in four eco-town projects currently under development. We critically analyze the eco-town initiative's policy evolution and early planning phase from a multilevel governance perspective by focusing on the following two interrelated aspects: (1) the evolving governance structures and resulting dynamics arising from the development of the eco-town initiative at UK governmental level, and the subsequent partial devolution to local stakeholders, including local authorities and nongovernmental actors, under the new 'localism' agenda; and (2) the effect of these governance dynamics on the conceptual and practical approach to adaptation through the emerging eco-town projects. As such, we problematize the impact of multilevel governance relations, and competing governance strategies and leadership, on shaping eco-town and related adaptation strategies and practice.
\end{abstract}

Key Words: English eco-towns; multilevel governance; UK climate change adaptation

\section{INTRODUCTION}

The English eco-town initiative was launched by the UK Labour government in 2007 to address the twin challenges of growing urbanization and climate change. In 2009, then Prime Minister Gordon Brown explained the two-fold policy objective for ecotowns as aiming "... to relieve the shortage of affordable homes to rent and buy, and minimize the effects of climate change on a major scale" (Jha 2009). However, since its launch, the initiative has experienced several significant political and policy shifts; in turn, this has affected both the governance structures within which it is being delivered, and the balance between socioeconomic and environmental sustainability goals at the heart of the initiative. As a case of adaptation for climate change, the English eco-town initiative provides useful insights into the framing of policy discourse, the delivery mechanisms and related policy dynamics, and the conceptual tensions resulting from complex multilevel governance processes.

Adaptation has been an integral part of the initiative, with both general references to "climate change resilience" and specific climate change adaptation elements, such as sea level rise and flood risk management, built into the policy (Communities and Local Government 2009). Importantly, however, these adaptation features have to be understood as running alongside other criteria, including climate mitigation and, arguably most dominant, socioeconomic sustainability features, that together form the ecotown initiative. Adaptation is, thus, subsumed within an overall broader policy frame. This partly reflects the conceptualization of climate change, at the time of the initiative's launch, in British policy concurrently in terms of mitigation and adaptation; as the national Planning Policy Statement: Planning and Climate Change clearly stated, "mitigation and adaptation should not be considered independently of each other, and new development should be planned with both in mind" (Communities and Local Government 2007a:11). It also partly reflects the main impetus for the initiative stemming from the Department of Communities and Local Government, which was responsible for producing a dominant socioeconomic frame. The eco-town initiative and its adaptation components, then, need to be analyzed in terms of the governance structures and mechanisms deployed, and how these have conditioned the framing and implementation of the policy, and vice versa. Here, of particular interest are what governance mode, including a specifically designed national planning policy to guide local implementation, and horizontal and vertical governance action levels, involving several governmental agencies, local authorities, and nongovernmental bodies, have been at work, and how these have coproduced the eco-town initiative.

A further, more general reason why adaptation forms a partial, albeit significant, component of the English eco-town initiative is that "eco-town" and similarly named "eco-city" and "sustainable city" initiatives typically engage with multiple facets of sustainability applied to the urban context. By its nature, the eco-city is characterized by several sustainability dimensions that concurrently engage with different policy areas applied to different urban scales, rather than addressing exclusively one policy area (Roseland 1997, Kenworthy 2006, Register 2006, Joss 2011a). As such, the English eco-town initiative belongs to a growing number of eco-city initiatives launched globally during the last 10-15 years (see, for example, World Bank 2010, UNHabitat 2011, Joss et al. 2013a,b). The diversity of approaches observed is in no small part explained by the influence of governance modes and action levels; indeed, the relationship between substantive aspects of urban sustainability and the governance mechanisms in play has been found to be a close and mutually reinforcing one (Rydin 2010, Joss 2011b). Notwithstanding this diversity, "ecological modernization," which aims to decouple economic development from negative environmental impacts, appears a common conceptual thread running through most contemporary eco-city initiatives. Programmatically, the "triple bottom line" of sustainability serves as a key organizing feature for most initiatives, although there is also often a tension, sometimes creative, sometimes problematic, at work between economic, social, and environmental dimensions.

Based on the methodological differentiation between "new build," "infill," and "retrofit" eco-city types (Joss 2011a, Caprotti 2014:12), the English eco-towns represent something of a crossover between "new build" and "infill" developments: they were 
originally defined as new settlements ( $\geq 10,000$ homes), envisaged as new towns built mainly on greenfield sites. In the course of planning, however, some initiatives, e.g., Whitehill-Bordon and North West Bicester, evolved as brownfield regeneration projects within existing municipal borders. As a major new town development program, the government originally promoted ecotowns as addressing the shortage of affordable homes, particularly in the southeast of England, while contributing to the UK's ambitious climate change mitigation and adaptation policies. However, since its launch, of the 10 initially selected sites only 4 have progressed to development stage, and only 1, North West Bicester, is currently being built based on the original Eco-Town Planning Policy Statement (ET-PPS) for England.

Our aim in this article, then, is to provide a critical, governancebased analysis of the eco-town initiative, with special focus on the evolution of the English eco-town initiative from its inception to the early implementation stage. The analysis focuses on the modes of governance through which the initiative has been framed nationally and has been devolved to the local level. In particular, we seek to understand the effects of the particular governance mechanisms in place, characterized by changing multilevel and multilateral governance interactions, on the contents and implementation process of the initiative. The consequences are analyzed of the shift from a mainly regulatory to a more marketoriented approach, combined with a shift from the national to local level. In turn, this helps inquire more generally into the significance of governing processes as a force shaping climate change adaptation and mitigation strategies.

Within this governance perspective, the analysis is guided by three main, interrelated research questions: (1) How has the English eco-town initiative evolved across vertical-horizontal governance structures? (2) What are the resulting governance processes, and what dynamics and tensions have arisen? (3) What has been the effect on the adaptation goal alongside economic sustainability considerations?

\section{CONCEPTUAL PERSPECTIVES}

The English eco-town initiative exhibits classic sustainable development (henceforth, SD) features: it was conceived of as part of a governmental sustainable communities policy and encompasses economic, social, as well as environmental dimensions, including goals for climate change adaptation. At the same time, it exhibits elements of (shifting) governance: it involves state and nonstate actors across national, regional, and local levels. Hence, it is particularly suited to an analysis of the interrelationship between governance and SD.

In recent years, there has been wide recognition of the closely intertwined and self-reinforcing relationship between governance and (urban) SD (see e.g., Kjaer 2004, Jordan 2008, Adger and Jordan 2009, Griffin 2010, Joss 2010, Roseland 2012). As Farrell et al. (2005:143) noted, sustainability is a political concept "replete with governance questions." It deals with, and cuts across, the economic, social, and environmental pillars of policy making. It does so at multiple levels, from the local to the global; and it involves a mixture of state and nonstate actors through new governance modes and instruments, such as public-private partnerships and participatory planning. This has prompted calls for more synergistic approaches to developing policies and implementing decisions than is the case with more traditional "command-and-control" policy and decision making. The case is made more compelling by the typically long-term nature of SD issues, as exemplified by climate change mitigation and adaptation strategies, which necessarily calls for governance beyond the short-term political or economic cycles. In addition, the often inherent complexity and uncertainty of sustainability issues, as the shifting discussion of climate change adaptation makes clear, requires shared knowledge and coordination across existing political boundaries and spheres of responsibility.

Nevertheless, in the era of governance, when dealing with issues such as sustainable urban development and related climate change adaptation strategies, the role of traditional government at various geographical levels and scales remains relevant, albeit within a broader context of decentralized, shared, and collective decision-making structures. Furthermore, it should not be read as given that a governance approach to sustainability necessarily delivers more effective or legitimate policy solutions compared with more traditional government mechanisms (see Griffin 2010). Research into a range of SD issues has shown that new forms of governance for sustainability can harbor problems, tensions, and contradictions of their own. For example, the blurring of responsibility in public-private partnerships, or the hybridity of state-initiated yet privately run bodies, can lead to blockages in decision making and cause public accountability problems (e.g., Book et al. 2010, Joss 2010). Elsewhere, research has indicated that governance mechanisms designed to reconcile economic and environmental sustainability goals may in fact exacerbate tensions between them (see Cochrane 2010, Joss 2010). Much of this has been shown to be closely dependent on the particular thematic, policy, and geographical contexts, within which governance for SD occurs.

The urban context is a particularly interesting avenue for the study of sustainability governance structures and governing processes, bringing together hierarchies, networks, and market mechanisms embedded in particular local settings (e.g., Greenwood and Newman 2010, Rydin 2010, Joss 2011b, Caprotti 2014). The dynamics and associated potential tensions arising vertically from central-local relationships, on one hand, and horizontally from various public-private and collaborative relationships are especially manifest in new organizational forms, such as for example local enterprise partnerships (LEPs) and other publicprivate partnerships (PPP) as recently deployed in the UK at the urban level. The additional cross-sectoral emphasis on SD within urban (regeneration) policy renders related governing processes yet more complex. This was illustrated, for example, in a recent analysis of the Thames Gateway, the UK's (and Europe's) largest urban regeneration project (Greenwood and Newman 2010): the aim of new governance, namely to join up strategic planning and development through increased horizontal, collaborative governing, was here found to be undermined by the still considerable influence wielded by traditional government structures. The relationship between traditional planning and new forms of governance was not yet fixed; in particular, the relationship between central government and local tiers of decision making were found to be undergoing continual change (Greenwood and Newman 2010). In turn, this was found to have detrimental effects on the extent to which SD policy implementation could be achieved. This continually changing relationship in both the vertical and horizontal governance 
arrangements has been a particular feature of UK urban SD policy, further exacerbated by the "localism" agenda introduced by central government in 2010 , and, consequently, has also had a bearing on the English eco-town initiative.

Elsewhere, recent research revealed how governance structures and processes codetermine the way in which SD dimensions are articulated within particular eco-city initiatives (Joss 2011b, Chan and Sheppard 2013, Shwayri 2013). This is especially relevant in the case of new-build and in-fill projects because these typically depend on new actor networks; although, again, government agency remains an important component of new governance arrangements. In the case of the English eco-town initiative, too, new governance processes have had to be put in place to facilitate its delivery. The UK context is particularly interesting given recent political devolution with its effects on national-regional-local interactions as well as public-private partnership arrangements. The eco-town initiative, with its dual focus on climate change mitigation and adaptation as well as urban expansion, has been fundamentally shaped by this changing governance context. Of particular interest, therefore, is to analyze the way in which the eco-town policy has been thematically framed as a result of a particular governance mode at work and how this has affected the articulation of adaptation goals within the policy; through which hybrid horizontal-vertical action levels the policy is to be implemented; and whether continual shifts in policy framing and governance mode have had any distorting effects.

\section{METHODOLOGY}

Based on the above conceptual framework, the focus of analysis in this article is the period of approximately 2003-2012. This is the period during which the English eco-town initiative began to take shape and progressed to initial implementation. It, thus, allows insight into the framing and formation of the national ecotown policy, and the governance mechanisms deployed to enable and encourage local uptake. It further provides insight into the early evolution and adaptation of this national policy in the context of a change in government. Because local implementation of individual eco-town initiatives is a more recent, ongoing process, it is not included in the discussion here.

Reflecting this focus, the analysis is based on a set of key official documents published since 2007 on the English eco-town initiative by relevant UK governmental departments, and particularly the Office of the Deputy Prime Minister (ODPM) and the Department of Communities and Local Government (DCLG). In addition, documentary analysis includes formative policy texts published in the period leading up to the launch of the initiative. The main policy documents include: Sustainable Communities: Building for the Future (Office of the Deputy Prime Minister 2003); Planning Policy Statement 1: Delivering Sustainable Development (Office of the Deputy Prime Minister 2005); Best Practice in Urban Extensions and New Settlements (Communities and Local Government 2007b); Planning Policy Statement: Planning \& Climate Change (Communities and Local Government 2007a); and Planning Policy Statement: Eco-towns (Communities and Local Government 2009). Also analyzed were: relevant consultation documents and parliamentary statements by the Department of Environment, Food and Rural Affairs (DEFRA) and the Department of Energy and Climate Change (DECC); documents by nongovernmental organizations, such as the Town and Country Planning Association (TCPA); and information by individual eco-town projects.

In addressing the core research questions, the aim of this documentary analysis was to produce a chronological mapping and relational analysis to trace the evolution of official policy and the emerging governance structures and processes shaping the contents of the eco-town initiative. As such, the present analysis gives insight into the initial phases of the initiative's life (2007-2012) based on official documents. Further research will have to be carried out in due course to shed light on the nature and extent of further implementation on the ground under the initiative's ongoing devolved administration.

\section{ANALYSIS}

The English eco-town initiative as national policy

When the eco-town initiative was launched in 2007 , its core policy objectives, to contribute to large-scale additional housing as well as to significant cuts in the UK's $\mathrm{CO}_{2}$ emissions, were covered by two government departments: DCLG, and DEFRA. A third department with responsibility in the area, DECC, was launched in 2008. However, significantly, the eco-town initiative was chiefly spearheaded by DCLG, with DEFRA and DECC only playing secondary roles. This arguably shaped the initiative in fundamental ways.

DCLG's dominant role came about as a result of the urban policy of the preceding 10 years. In 1997, the incoming Labour government sought to address two major policy issues concerning urban planning reform. Climate change mitigation and adaptation moved centre stage in policy making, following the adoption of the Kyoto Protocol by the international community. In the ensuing years, the UK government became a leader in the field, culminating in the Climate Change and Sustainable Energy Act (2006), the Climate Change Act (2008), and the launch of DECC in the same year. Innovation in urban sustainability and energy efficiency relating to both existing and new urban areas were among several governmental efforts supported through national policy. At the same time, the planning legacy of the 1980s and 1990s, which had provided a boon for commercial property development, meant that there was a need to redress urban development in favor of (affordable) residential housing. There, thus, arose a potent dual policy need, namely, implementing climate change policy measures in tandem with embarking on a significant urban development program.

The formulation of the new housing policy fell to Deputy Prime Minister John Prescott, following the incorporation of the local government and regions portfolio in the Cabinet Office in 2001. The policy was predicated on greater direct governmental intervention and national regulation than under the previous government, to enable concerted, directive action. It is within this political context that the influential Sustainable Communities: Building for the Future policy document was published (Office of the Deputy Prime Minister 2003). Notably, however, the report did not feature DEFRA, not even as one of the consulted agencies. Consequently, the report's thrust was on the need to build more residential homes, namely, a minimum of 155,000 additional houses year-on-year for a period of up to 20 years (Office of the Deputy Prime Minister 2003). The focus on urban development, without integration of climate change mitigation and adaptation 
measures, was obvious also from the allocation of financial resources: the only program specifically aimed at improving the "local environment" and "livability" in 2002-2003 received a modest $£ 13$ million out of a total of $£ 5$.5 billion allocated (Office of the Deputy Prime Minister 2003). Environmental issues were, therefore, peripheral to the policy; in so far as they did get a mention they focused on maintaining the greenbelt around urban areas and improving urban parks and public spaces (Office of the Deputy Prime Minister 2003). The "sustainable development" section of the report emphasized socioeconomic aspects in terms of the need for a substantial increase of homes in the southeast of England. Environmental aspects were mentioned "in regard to addressing flood risks" with reference to the Environment Agency (Office of the Deputy Prime Minister 2003:49).

The Sustainable Communities plan was soon followed by the Review of Housing Supply (Barker 2004). The report reinforced the conclusion that the limited housing supply had led to an unsustainable increase in house prices, which needed to be addressed by increasing the housing supply in general, and the number of affordable homes in particular. The report was notable by the absence of any direct reference to climate change and other environmental sustainability issues relating to the proposed significant expansion of urban development across England.

Taken together, the two reports reflected urban planning/ urbanization policy in the early 2000s, which was not as yet directly connected to climate change and other environmental goals. The two agendas were finally brought together more explicitly in 2007 with the publication of the Guidance on New Settlements and Urban Extensions by the Town and Country Planning Association (TCPA 2007, Manns 2008). The report paved the way for the launch of the English eco-town initiative and new town developments. It was significant in that it recommended a dual strategy for regeneration and "greening": "regeneration and greening are not incompatible opposites: they are both necessary parts of any overall development programme" (TCPA 2007:2). The report was followed shortly afterward, in March 2007, by Prime Minister Blair's announcement of plans for five new eco-towns for England. (The eco-town initiative, although a UK government policy, only applied to England, due to the devolved political structures introduced in 1998.) The government's Eco-town Prospectus was published later that summer (Communities and Local Government 2007c) and confirmed the twin strategy of regeneration-cum-greening espoused by the TCPA report. The initiative, then, was an example of a more interventionist approach to urban planning, with clear steering to be provided by central government. The eco-towns were to be exemplar green developments, to prove the viability of sustainable living, among others, through zero-carbon homes and a shift to renewable, low-carbon energy, and to act as template for replication elsewhere (Communities and Local Government 2009). While a national policy, individual eco-towns were nevertheless to be defined by local characteristics and to be implemented and monitored by local authorities.

Despite the twin, cross-sectoral policy goal, DCLG retained ownership over the initiative, with DEFRA and (from 2008) DECC playing only a subsidiary role. The involvement of DEFRA and the Environment Agency was limited to consultee status on environmental aspects of the policy, as part of which it was "supportive of the eco-towns concept and welcomes our continued involvement in the process" (DEFRA 2007:1). Similarly, DECC, did not (manage to) get directly involved in the emerging eco-town policy. There was, then, a certain bias, in terms of both conceptualization and governance, built into the eco-town initiative from its initial conception.

Prime Minister Brown, new in post in 2007, announced the doubling of the number of eco-towns, to 10 . This was followed by various practical interventions aimed at supporting related design, planning, and implementation. For example, the TCPA launched its Zero Carbon Development Task Force, while the Prince's Foundation started running master classes in creating eco-towns in Britain, to provide local authorities with guidance on how to submit proposals for hosting an eco-town, as part of the national consultation process. By early 2008, 57 formal bids had been received from across England. However, if the profile of the new eco-town initiative seemed to be increasing, so did the opposition to the scheme. One criticism was that the initiative was used to revive previously rejected planning applications, such as the proposed "Ford Eco Town" project (Oakeshott 2008). Elsewhere, the public consultation on the proposed Eco-Town Planning Policy Statement (ET-PPS) as statutory planning policy tool triggered some skepticism by the planning community. For example, David Lock, former TCPA president, raised concerns that the ET-PPS would "force through eco-towns by crashing the planning process" (Oakeshott 2008), by reducing the ability of planners to oppose development on greenfield sites. Similarly, the proposed ET-PPS was criticized for the apparent lack of integrated infrastructure at the heart of eco-towns: "a PPS which directs separation of eco-towns into isolated eco-enclaves is folly and will grind to a standstill in the planning system"(Twinn 2009).

By summer 2008, detailed planning work had begun on the 15 short-listed projects. In July 2009, the ET-PPS was published and the first four selected locations were announced: WhitehillBordon, St Austell, Rackheath, and North West Bicester. The government pledged to contribute $£ 60$ million in support of local infrastructure investment to integrate the four new eco-towns into existing communities, thus responding to earlier criticism. The UK general election of May 2010 and the subsequent change of government found the English eco-town initiative at the beginning of its implementation phase. As it turned out, the change of government also signaled the beginning of the end of the ecotown initiative as national policy.

Concerning the adaptation elements, these appear across several key policy documents. In particular, the Planning Policy Statement 1: Delivering Sustainable Development (Office of the Deputy Prime Minister 2005), of which the subsequent Planning and Climate Change (Communities and Local Government 2007a) and Eco-town (Communities and Local Government 2009) planning policy statements were both supplements, states: "Regional planning bodies and local planning authorities should ensure that development plans contribute to global sustainability by addressing the causes and potential impacts of climate change ... and take climate change impacts into account in the location and design of development" (Office of the Deputy Prime Minister 2005:6). Elsewhere, the Planning Policy Statement 1: Delivering Sustainable Development states that: "Development plan policies should take account of environmental issues such as: mitigation 
of the effects of, and adaptation to, climate change [and] the potential impact of the environment on the proposed developments by avoiding new development in areas at risk of flooding and sea-level rise" (Office of the Deputy Prime Minister 2005:8). An adaptation discourse is, thus, built into the planning specifications informing the eco-town initiative. However, this forms a relatively small part of a wider discourse defined more explicitly in terms of SD.

References to adaptation become more pronounced in both of the later supplementary policy documents. The ET-PPS (2009) states that: "it is the government's view that eco-towns should be exemplar projects that encourage and enable residents to live within managed environmental limits and in communities that are resilient to climate change" (Communities and Local Government 2009:2). Following from this, the document includes a separate section on climate change adaptation framed as follows: "Eco-towns should be sustainable communities that are resilient to and appropriate for the climate change now accepted as inevitable" (Communities and Local Government 2009:6). This is followed by a series of specific recommendations.

\section{The impact of new localism}

The UK coalition government (2010-) has pursued a policy agenda predicated on less direct state involvement in urban planning and, in effect, a certain return to 1980 s-1990s policy. Its Localism Act (HM Government 2011) paved the way for more locally directed and market-driven approaches. Although the government retains direct planning involvement in large-scale projects, e.g., power stations, renewable energy arrays, airports, responsibility for urban/residential developments has been devolved to local authorities and local economic partnerships (LEPs). The act also spelt the end for the Regional Development Agencies (RDAs), except for the retention of the Greater London Authority, that had been established in 1998 under the previous government's devolution agenda for England. Hence, "Regional Plans," which many saw as an important tool for coordinating developments at regional level, have become defunct. The government's argument was that "... revoking the [Regional] Plans will protect communities and the environment from top-down pressure" and, in doing so, "putting planning powers into the hands of local people to take charge of local housing challenges in a way that makes sense for them, while protecting the local countryside and green spaces they value" (Neill 2011). Therefore, under the current administration, localism has to be understood as a three-fold development: devolution to local authority level; increased involvement of nongovernmental actors in policy delivery through LEPs; and the reduction and relaxation of planning policy. Under the Localism Act, local authorities are given "general power of competence" whereby "local authorities are able to do anything an individual can do unless specifically prohibited by law" (Local Government Lawyer 2012).

As a result of this policy shift, responsibility for the four designated eco-town sites has been devolved, with the local authorities concerned solely in charge of developing and implementing eco-town policy. Interestingly, despite being significant new settlements of over 5000 homes and requiring substantial new infrastructure, the government did not categorize them as large-scale projects, thus devolving responsibility to local actors. The eco-town initiative is, therefore, effectively no longer a national initiative and no longer bound by national policy informing the relationship between urban development and regeneration, on one hand, and climate change mitigation and adaptation, on the other. Central government funding has been significantly reduced (except for $£ 6$ million funding for 199 affordable houses in North West Bicester); the ET-PPS was withdrawn as a compulsory planning tool; and the eco-town web pages on the DCLG web site were removed. Of the four eco-town initiatives, only North West Bicester continues to be developed using the now voluntary ET-PPS.

To redress central government disengagement, local governance solutions are in the process of being put in place. WhitehillBordon, for example, has developed an elaborate governance structure consisting of a standing conference for citizen participation, specialist groups focusing on infrastructure, housing, and SD, and a delivery board bringing together relevant decision makers. The latter has no statutory powers, relying instead on its members to implement agreed policy via their organizations. Similarly, North West Bicester (now called Eco Bicester) has put in place a strategic delivery board, which brings together local councillors and members of the public. The effectiveness of these local governance structures will partly depend on the ability of local actors to raise the necessary funding, and partly on how well the climate change mitigation and adaptation goals are maintained following the withdrawal of the ET-PPS as a formal planning tool.

It, thus, remains to be seen how viable the remaining, localized eco-town projects will be in the long run and whether they will spawn further initiatives. What is clear is that the eco-town initiative has lost its national policy status and lacks a coherent policy framework, thus severing the link between national policy (on climate change and urban regeneration) and local development in significant way. For the four ongoing projects, the risk under the present regime is that local authorities may not have sufficient resources and expertise without wider support. Currently, the Eco Bicester and Whitehill-Bordon initiatives appear to be moving forward with their respective developments, while St Austell eco-town is reportedly "on hold" (BBC 2012). Significantly, the latter blames "a planning framework still in a state of evolution" as much for the impasse, as the current economic downturn (BBC 2012). The promoters of the Rackheath eco-town have sought to reassure supporters that "... the pioneering green development is still very much in progress, despite the current challenging economic climate" (Sustainable Building Matters [date unknown]).

\section{DISCUSSION}

The example of the English eco-town initiatives highlights the complexity of contemporary urban panning policy based on the twin goals of urbanization and climate change adaptation, as pursued through eco-city initiatives of various kinds. This complexity does not only arise from having to reconcile largescale urban economic development, in the UK, an estimated $150,000+$ additional homes are required annually, with efforts to cut $\mathrm{CO}_{2}$ emissions (for the UK, a statutory obligation to cut $80 \%$ by 2050); it also arises from having to implement such policy through multilevel and multilateral governance arrangements. As this case shows, governance structures and related dynamics have an important bearing on the contents and course of sustainability 
policy: here, in particular, the articulation of the balance between socioeconomic (additional housing) and environmental (climate change) goals of SD. This case also demonstrates how governance arrangements evolve across time resulting in shifting priorities. Furthermore, it demonstrates the continuous, important governmental influence in shaping policy, even where government wishes to act at a distance by promoting devolved governance arrangements.

The English eco-town initiative was beset by certain conceptual and structural tensions arising from its particular multilevel governance set-up. These tensions manifested themselves horizontally at (national) governmental level, as well as vertically between national and local levels; and they became more prominent as a result of a significantly changing national policy and political context.

Considering the initiative's policy conceptualization, the primacy of the urbanization rationale was obvious from the start. It was the Labour government's policy on affordable housing, rooted in the Sustainable Communities: Building for the Future report and the Barker Review, that gave rise to the initiative in the first instance. Within this framework, sustainable communities was mainly understood in terms of a socioeconomic growth agenda and less so as an environmental agenda. The latter was only properly introduced at a relatively late stage, upon the initiative's launch. This created something of a tilted governance structure from the outset, with DCLG in the driving seat. There was little evidence of an attempt made to rebalance the relationship between DCLG, DEFRA, and DECC through a more joined-up development and delivery of the eco-town policy.

The rationale for new modes of governance is precisely the advantage of joined-up policy- and decision-making processes to achieve better coordination across organizations and sectors. A more integrated governance approach would certainly have been called for in the case of the eco-town initiative, given the national policy significance of both climate change resilience and urban development, and the overlapping interests by the three government departments concerned. A more coherent coalition of interests and more concerted efforts might well have yielded a more significant and lasting legacy.

As it turned out, the predominance of the DCLG was arguably the eco-town initiative's undoing as national policy. The main reason for this lies in the change of government in 2010, which brought about a significant shift in government direction on communities and local government in general, and (local) planning in particular. As noted, under the Labour administration (1997-2010), national policy favored a more statecentric, interventionist approach to urban and environmental planning; under the current coalition government (2010-), policy is predicated on localism. This shift has particularly affected policies relating to DCLG, with the main focus on reforming planning policy through deregulation and devolution, much more so than those of DEFRA and DECC. Consequently, it also destabilized the eco-town initiative, as evidenced by the withdrawal of infrastructure funding and the ET-PPS. One can only speculate whether a stronger alliance between the three departments, and associated stakeholder groups, from the outset would have secured the initiative's continuation under the current government. As it happened, the strong focus of the sustainable communities agenda in the early 2000s on socioeconomic sustainability (additional affordable housing) set in motion a policy direction that translated into a stronghold of DCLG over the initiative.

If the government in 2007 arguably failed to achieve effective horizontal, cross-sectoral integration, the subsequent government in 2010 arguably failed to provide sufficient vertical governance coordination to sustain the initiative. Abandoning the ET-PPS as national planning mechanism for eco-towns and withdrawing core infrastructure funding arguably shifted the balance between central and local decision making too far in the latter's direction, resulting in an approach that lacks coherence and sufficient scale. Coordinating policy development and steering practice learning across individual sites, a central task for government even, and particularly, within new mode governance, is now effectively left entirely to local actors involved in the four initiatives. In a telling sign of the government's disengagement with the initiative, Deputy Prime Minister Clegg during a visit to Eco Bicester in 2012 urged that "we need more of this kind of ambition," while at the same time making it clear where responsibility rests, namely, with local actors, and not government (Friends of NW Bicester 2012). Whether, beyond the immediate challenge of keeping their local initiatives going, these local actors have the capacity to contribute to nationally significant adaptation policy innovation is an open question.

By the former and current government's own admission, a sustained program of house building is required over the next couple of decades to redress the current supply shortage and meet expected future demands, while concurrently significant efforts are required to achieve a systemic transition to a low-carbon economy to meet the government's ambitious greenhouse gas emission targets by 2050 . Such a long-term planning horizon is typically also mirrored within individual eco-town and eco-city initiatives, with development not infrequently taking $15-25$ years to completion (Joss 2011b). Here, too, the example of the ecotown initiative points to a failure to provide an effective governance framework which is endurable across the necessary time spectrum, from initial policy development through to project implementation. This was ultimately due to a lack of a sufficiently strong political consensus in place to steer a long-term initiative of this kind through different electoral cycles and political regimes.

\section{CONCLUSIONS}

We set out to analyze the English eco-town initiative from a governance perspective. The analysis points to the intricate and at times problematic relationship between, on one hand, governance structures and processes and, on the other, the evolving conceptualization, development, and implementation of the eco-town policy. It suggests considerable governance tensions at work, arising from skewed governance structures and a lack of effective horizontal and vertical policy coordination, which, in turn, created significant substantive tensions. The previous government failed to redress the balance, conceptual and governance, when in the latter part of the 2000 s the opportunity arose with the introduction of governmental climate change policy. The current government also failed to redress the balance and, it is feared, may have irreparably damaged the prospect of the English eco-town policy succeeding, following its effective 
disengagement with the initiative as national policy. The initiative, thus, also reveals the uncertainty created by ongoing adjustments in the policy approach and governance mode. Although to some extent such adjustment is to be expected as part of an evolving initiative, for example, reflecting shifts in international policy discourse or advances in technological development, in the case of the English eco-towns this was exacerbated by continual, and arguably disruptive, change in the governance approach due in no small part to the change in national government in 2010 and its subsequent impact on national planning policy and practice.

The significance of the English eco-town initiative as an adaptation, and wider urban sustainability strategy, therefore, remains to be seen. It will depend, on one hand, on whether the remaining four eco-town projects can retain, beyond their individual reach, something of the originally intended wider model function and stimulate a vibrant eco-town practice across the UK, even in the absence of an intact national framework and related government backing. On the other, it will depend on how the adaptation elements consolidate through the evolving initiatives. The original eco-town policy did not conceptually discern between mitigation and adaptation, on the contrary, early policy insisted on the two being considered in tandem as part of UK climate change policy. A few, specific adaptation strategies were, however, articulated as part of the subsequent selection and planning process, such as the stipulation that no new developments should be built in areas considered at risk from flooding. As and if the eco-town initiatives progress further, the adaptation element may come more to the fore, reflecting the gradual shift toward more explicit adaptation strategies in UK planning policy discourse at present.

The current reliance on local actors to develop expertise, coordinate planning and implementation, and secure funding for the four eco-town projects may seem a somewhat risky strategy, given the UK government's commitment to meeting its own stringent climate change targets, to which it is committed through its pioneering climate change act, and providing much needed additional housing. In addition, the lack of a clear national policy direction may also undermine the UK's ambition to secure an internationally recognized, credible role as innovator in urban sustainability and related climate change policy, against stiff competition from competitors, such as France, Germany, and Sweden. By comparison, it is interesting to note that other national programs, such as the French initiatives Écocité, launched in 2008 and since grown to 19 cities, and ÉcoQuartier, launched in parallel and including 14 towns, and the Japanese eco-city program launched in 2009 and including 13 cities selected from 82 applications, have each pursued similar approaches in the same period of time: a national policy incentivizing and guiding local initiatives, with local uptake encouraged through flexible governance modes, e.g., public-private partnerships, etc. (Joss et al. 2013a). In contrast to the English eco-town initiative, however, these programs have so far enjoyed more enduring governmental support, even across changes in government, based on more solid national policy frameworks and sustained financial and planning incentives. Furthermore, they are now being used to spearhead the two countries' foray into international eco-city activities: the French ÉcoQuartier concept is being piloted in China through a
Sino-French collaboration focusing on three cities (Chengdu, Chongqing, Shenyang), while the Indian eco-town concept for the four planned new eco-friendly cities (Changodar, Dahej, Manesar Bawal, Shendra) along the Delhi-Mumbai Corridor is based on the Japanese Kitakyushu eco-town model.

Finally, the case of the English eco-town initiative and in particular the initiative's limited progress to date, both in terms of its scale and rate of implementation, point to wider conceptual lessons concerning the governance of (urban) sustainability and climate change (adaptation) strategies: this concerns the need for more concerted governance integration and coordination across sectors and tiers of decision making to enable effective policy innovation and implementation. This also highlights, yet again, the importance of integration in terms of the triple bottom-line of sustainability. Coordination across government levels and policy continuity across electoral cycles, therefore, remain paramount to achieving a coherent, long-term adaptation policy capable of addressing environmental as well as socioeconomic needs.

Responses to this article can be read online at: http://www.ecologyandsociety.org/issues/responses. $\mathrm{php} / 6411$

\begin{abstract}
Acknowledgments:
A preliminary version of the paper was presented at The Governance of Adaptation conference, Amsterdam, 2012
\end{abstract}

\section{LITERATURE CITED}

Adger, N. W., and A. J. Jordan. 2009. Governing sustainability. Cambridge University Press, Cambridge, UK.

Barker, K. 2004. Review of housing supply. Her Majesty' Stationery Office, Norwich, UK.

BBC. 2012. St Austell's eco town project 'on hold'. 5 December. [online] URL: http://www.bbc.com/news/uk-england-cornwall-20606304

Book, K., L. Eskilsson, and J. Khan. 2010. Governing the balance between sustainability and competitiveness in urban planning: the case of the Orestad model. Environmental Policy and Governance 20(6):382-396. http://dx.doi.org/10.1002/eet.557

Caprotti, F. 2014. Critical research on eco-cities? A walk through the Sino-Singapore Tianjin Eco-City, China. Cities 36:10-17. http://dx.doi.org/10.1016/j.cities.2013.08.005

Chan, I.-C. C., and E. Sheppard. 2013. China's eco-cities as variegated urban sustainability: Dongtan Eco-City and Chongming Eco-Island. Journal of Urban Technology 20 (1):57-75. http://dx.doi.org/10.1080/10630732.2012.735104

Cochrane, A. 2010. Exploring the regional politics of 'sustainability': making up sustainable communities in the SouthEast of England. Environmental Policy and Governance 20 (6):370-381. http://dx.doi.org/10.1002/eet.556 
Communities and Local Government. 2007b. Best practice in urban extensions and new settlements. Town and Country Planning Association, London, UK.

Communities and Local Government. 2007c. Eco-town Prospectus. Department for Communities and Local Government, London, UK.

Communities and Local Government. 2007a. Planning policy statement: planning and climate change. Department for Communities and Local Government, London, UK.

Communities and Local Government. 2009. Planning policy statement: eco-town. Department for Communities and Local Government, London, UK.

Department for Environment Food and Rural Affairs (DEFRA). 2007. Response to communities and local government eco-towns stage 2 consultation; draft planning policy statement sustainability appraisal and habitats regulation assessment. DEFRA, London, UK. [online] URL: http://test.environment-agency.gov.uk/static/ documents/Research/1996_Eco-towns.pdf

Farrell, K., R. Kemp, F. Hinterberger, C. Rammel, and R. Ziegler. 2005. From *for* to governance for sustainable development in Europe: what is at stake for future research? International Journal of Sustainable Development 8(1/2):126-150. http://dx.doi. org/10.1504/IJSD.2005.007379

Friends of NW Bicester. 2012. Deputy Prime Minister Nick Clegg welcomes 'vision and ambition' for North West Bicester. Bicester, UK. http://nwbicester.co.uk/2012/11/deputy-prime-minister-nickclegg-welcomes-vision-and-ambition-for-north-west-bicester/

Greenwood, D., and P. Newman. 2010. Markets, large projects and sustainable development: traditional and new planning in the Thames Gateway. Urban Studies 47(1):105-119. http://dx.doi. org/10.1177/0042098009346864

Griffin, L. 2010. Governance innovation for sustainability: exploring the tensions and dilemmas. Environmental Policy and Governance 20(6):365-369. http://dx.doi.org/10.1002/eet.555

HM Government. 2011. Localism act. UK Government, London, UK. http://www.legislation.gov.uk/ukpga/2011/20/contents/enacted

Jha, A. 2009. Four ecotowns given the green light. Guardian, 16 July. [online] URL: http://www.theguardian.com/environment/2009/ jul/16/ecotowns

Jordan, A. 2008. The governance of sustainable development: taking stock and looking forwards. Environment and Planning $C$ 26(1):17-33. http://dx.doi.org/10.1068/cav6

Joss, S. 2010. Accountable governance, accountable sustainability? A case study of accountability in the governance for sustainability. Environmental Policy and Governance 20(6):408-421. http://dx. doi.org/10.1002/eet.559

Joss, S. 2011a. Eco-cities: the mainstreaming of urban sustainability; key characteristics and driving factors. International Journal of Sustainable Development and Planning 6 (3):268-285. http://dx.doi.org/10.2495/SDP-V6-N3-268-285

Joss, S. 2011b. Eco-city governance: a case study of Treasure Island and Sonoma Mountain Village. Journal of Environmental Policy and Planning 13(4):331-348. http://dx.doi.

org/10.1080/1523908X.2011.611288
Joss, S., R. Cowley, and D. Tomozeiu. 2013a. Towards the 'ubiquitous eco-city': an analysis of the internalisation of ecocity policy and practice. Urban Research \& Practice 6(1):54-74. http://dx.doi.org/0.1080/17535069.2012.762216

Joss, S., R. H. Kargon, and A. P. Molella, editors. 2013b. Special Issue: Eco-cities in Pan-Asia: international discourses, local practices. Journal of Urban Technology 20(1).

Kenworthy, J. R. 2006. The eco-city: ten key transport and planning dimensions for sustainable city development. Environment \& Urbanization 18(1):67-85. http://dx.doi. org/10.1177/0956247806063947

Kjær, A. M. 2004. Governance. Polity, Cambridge, UK.

Local Government Lawyer. 2012. Pickles fast-tracks general power of competence in bid to overtake prayer ruling. 20 February. [online] URL: http://www.localgovernmentlawyer.co.uk/index. php?option $=$ com content $\&$ view $=$ article $\&$ id $=9464 \% 3$ Apickles-fasttracks-general-power-of-competence-in-bid-to-overtake-prayerruling\&catid $=56 \% 3$ Alitigation-articles $\&$ Itemid $=1$

Manns, J. 2008. Eco-towns, New Labour and sustainable residential development. People, Place and Policy 2(3):132-139. http://dx.doi.org/10.3351/ppp.0002.0003.0003

Neill, B. 2011. Government moves ahead with plans to abolish regional plans and protect the green belt. Department for Communities and Local Government, London, UK. [online] URL: http://www.communities.gov.uk/news/corporate/200951211

Oakeshott, I. 2008. Whitehall to force through eco-towns. Times, 18 May.

Office of the Deputy Prime Minister. 2003. Sustainable communities: building for the future. Office of the Deputy Prime Minister, London, UK.

Office of the Deputy Prime Minister. 2005. Planning policy statement 1: delivering sustainable development. Her Majesty's Stationery Office, Norwich, UK.

Register, R. 2006. Ecocities. Rebuilding cities in balance with nature. New Society Publishers, Gabriola Island, British Columbia, Canada.

Roseland, M., editor. 1997. Eco-city dimensions. Healthy communities, healthy planet. New Society Publishers, Gabriola Island, British Columbia, Canada.

Roseland, M. 2012. Toward sustainable communities. Solutions for citizens and their governments. Fourth edition. New Society Publishers, Gabriola Island, British Columbia, Canada.

Rydin, Y. 2010. Governing for sustainable urban development. Earthscan, London, UK.

Shwayri, S. T. 2013. A model Korean ubiquitous eco-city? The politics of making Songdo. Journal of Urban Technology 20 (1):39-55. http://dx.doi.org/10.1080/10630732.2012.735409

Sustainable Building Matters. [date unknown]. Promoters of the Rackheath Eco-Community reassure supporters. Sustainable Building Matters, Bicester, UK. [online] URL: http://www. sbmsearch.com/article/229 
Town and Country Planning Association (TCPA). 2007. Guidance on new settlements and urban extensions. TCPA, London, UK.

Twinn, C. 2009. Government policy on eco-towns doesn't consider the wider community. Edge Debate. [online] URL: http://www. edgedebate.com/?s=Government + policy + on + eco-towns + doesn $\%$ $\underline{27 \mathrm{t}+\text { consider }+ \text { the }+ \text { wider }+ \text { community \& submit }=\mathrm{GO}}$

UN-Habitat. 2011. Cities and climate change: global report on human settlements 2011. Earthscan, London, UK.

Whitehill Bordon Eco-Town. 2001. One planet living in Whitehill Bordon. Whitehill Bordon, UK. [online] URL: http://www. whitehillbordon.com/wp-content/uploads/2011/08/One-Planet-LivingStrategy.pdf

World Bank. 2010. Eco2 cities: ecological cities as economic cities. The World Bank, Washington, D.C., USA. 